\title{
16. LATE PLIOCENE TO HOLOCENE (2.6-0 MA) WESTERN EQUATORIAL ATLANTIC DEEP-WATER CIRCULATION: INFERENCES FROM BENTHIC STABLE ISOTOPES ${ }^{1}$
}

\author{
T. Bickert, ${ }^{2}$ W.B. Curry, ${ }^{3}$ and G. Wefer ${ }^{2}$
}

\begin{abstract}
Oxygen and carbon isotope records measured in epibenthic foraminifers (Cibicides wuellerstorfi, Cibicides spp., and Nuttalides umbonifera) are presented for Sites 925 (3041 m water depth), $927(3315 \mathrm{~m})$, and $929(4356 \mathrm{~m})$, recovered during Ocean Drilling Program (ODP) Leg 154 at the northeast slope of the Ceara Rise, western equatorial Atlantic. These records comprise the time interval from 2.6 to $0 \mathrm{Ma}$. Dating is based on tuning variations of the magnetic susceptibility records to orbital parameters using the 1,1 solution of Laskar.

The isotope records of all sites are exceptionally coherent and show a cyclicity dominated by a 41-k.y. cycle during the late Pliocene and the early Pleistocene and a 100-k.y. cyclicity during the late Pleistocene. Carbon isotope records show a varying depth gradient during the studied period. For interglacials, a difference of $0.3 \%$ reflects the modern pattern of admixing of Lower Circumpolar Deep Water into the overlying North Atlantic Deep Water (NADW). During glacials, carbon isotope values of shallow and deep sites differ by up to $1.0 \%$, but converge since $1.6 \mathrm{Ma}$, and especially since $1.0 \mathrm{Ma}$.

The evolution of Atlantic to Pacific carbon isotope gradients is examined using a record of the western equatorial Pacific ODP Site 806B $(2520 \mathrm{~m})$. From 2.6 to 1.6 Ma glacial reductions in NADW are less than those observed between 1.6 and $0 \mathrm{Ma}$. During the mid-Pleistocene (0.7-0.3 Ma), glacial carbon isotope values of even the shallower Atlantic cores are indistinguishable from Pacific values from approximately the same depth.
\end{abstract}

\section{INTRODUCTION}

Variations in the relative flux of North Atlantic Deep Water (NADW) to the Southern Ocean have been implicated as a driving force in the growth and decay of continental ice sheets because this deep-water mass plays a major role in the interhemispheric heat and salt exchange (Broecker and Denton, 1989; Imbrie et al., 1992, 1993). It may also influence the chemical properties of Southern Ocean surface waters and may, for example, result in atmospheric $\mathrm{CO}_{2}$ changes due to the impact on ocean water alkalinity (Boyle, 1988; Broecker and Peng, 1989; Charles and Fairbanks, 1992). Raymo et al. (1990) examined the evolution of deep ocean $\delta^{13} \mathrm{C}$ gradients for the last $2.5 \mathrm{Ma}$ and found that glacial reductions in NADW were less intense between 2.5 and $1.5 \mathrm{Ma}$ as compared with those in the late Pleistocene. At a number of times during this latter interval, the $\delta^{13} \mathrm{C}$ at Deep Sea Drilling Program (DSDP) Site $607\left(41^{\circ} \mathrm{N}, 33^{\circ} \mathrm{W}\right.$, $3427 \mathrm{~m}$ ) in the North Atlantic were indistinguishable from the eastern equatorial Pacific values from about the same depth. Maxima in the primary record of the NADW production (Site 607) lag minimum ice volume. But there is evidence from other deep-water proxies, such as the foraminiferal $\mathrm{Cd} / \mathrm{Ca}$ record from the South Atlantic (Oppo and Rosenthal, 1994), that suggest NADW production has the opposite phasing: maxima in NADW production occur during ice growth.

Of course, until now, studies of the connection between deep-water production and climate changes on longer time scales (i.e., the last several million years) only relies on a very few records of deep-water circulation, and some of these records are probably not ideally located to monitor the critical deep-water components. For example, Mix et al. (1995) and Bickert et al. (in press) showed that the eastern Pacific Ocean Drilling Program (ODP) Site $677\left(1^{\circ} \mathrm{N}, 84^{\circ} \mathrm{W}, 3461 \mathrm{~m}\right)$

${ }^{1}$ Shackleton, N.J., Curry, W.B., Richter, C., and Bralower, T.J. (Eds.), 1997. Proc. ODP, Sci. Results, 154: College Station, TX (Ocean Drilling Program).

${ }^{2}$ Fachbereich Geowissenschaften, Universität Bremen, 28334 Bremen, Federal Republic of Germany. bickert@zfn.uni-bremen.de

${ }^{3}$ Department of Geology, Woods Hole Oceanographic Institution, Woods Hole, MA 02543, U.S.A. benthic $\delta^{13} \mathrm{C}$ record does not serve as an appropriate Pacific deep-water reference because it reflects additional local variations in low$\delta^{13} \mathrm{C}$ organic matter contributing to $\Sigma \mathrm{CO}_{2}$ in the relatively isolated Panama Basin. Our understanding of deep-water circulation and its link to climate would be enhanced greatly by new records that provide deep water proxy measurements with unambiguous interpretations and that are especially sensitive to changes in deep-water formation.

In the study presented here, we use three of five sites, drilled along a depth transect on Ceara Rise during ODP Leg 154 in 1994 (Fig.1), to provide deep-water proxy records in a region that is sensitive to changes in NADW production. The history of deep-water circulation for the last 2.6 Ma will be reconstructed using measurements of benthic foraminiferal $\delta^{13} \mathrm{C}$. Due to the fact that the analyses are still in a status nascendi, the purpose of this paper is (1) to provide a high resolution age model for all five sites by tuning their magnetic susceptibility records to an orbital target, (2) to present a high resolution benthic isotope record of the shallowest Site 925 as a reference for the depth transect and as an independent check for the tuning by comparing its oxygen isotope record to the Site 677 record (Shackleton et al., 1990), (3) to compare the $\delta^{13} \mathrm{C}$ record of this location to other $\delta^{13} \mathrm{C}$ records (Site 607 in the northern Atlantic, Site 659 in the eastern equatorial Atlantic, and Site 806 in the western Pacific), and (4) to present first results of the depth gradients between two shallow sites $(925,927)$ and the deepest site $(929)$ in the time interval between 0 and 2.6 Ma.

\section{STUDY AREA}

Today the circulation in the deep western Atlantic, the main flow path of deep-water, is dominated by interactions between NADW flowing toward the south and Circumpolar Deep Water (CDW) flowing to the north. The density characteristics of these water masses are such that NADW divides the southern water mass into an upper and lower branch. Consequently, the relatively warm and saline NADW occupies the depth interval between 2000 and 4000 m, whereas lower 

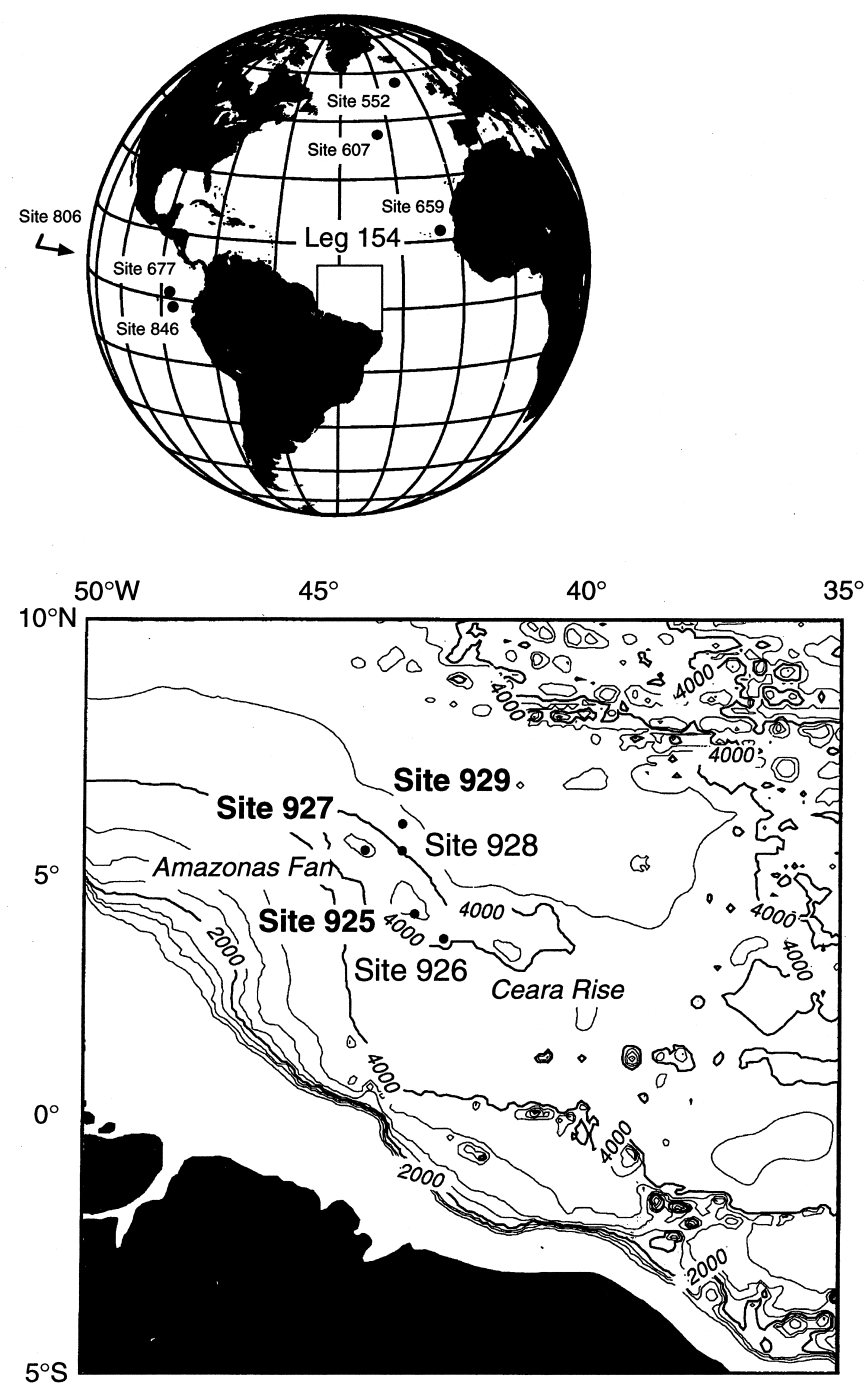

Figure 1. Location map showing the positions of the Sites 925 through 929 drilled during Leg 154 on Ceara Rise and the positions of other sites discussed in this study.

CDW (LCDW) is encountered below $4000 \mathrm{~m}$. The mixing zone between NADW and LCDW is marked by gradients in temperature, salinity, nutrient concentrations, and corrosiveness of the water with respect to calcium carbonate (Fig. 2). The depth of lysocline today is about 4500 m, just below the depth of Site 929.

The carbon isotopic composition of $\sum \mathrm{CO}_{2}$ is linked to deep-water circulation patterns because its distribution in sea water is affected by photosynthesis and respiration. Deep water that is formed with a significant surface water component, like NADW today, is enriched in ${ }^{13} \mathrm{C}$ because photosynthesis has preferentially removed ${ }^{12} \mathrm{C}$ from the $\sum \mathrm{CO}_{2}$ of the surface water. CDW, as an old water mass, has lower $\delta^{13} \mathrm{C}$ values because nearly all of the organic matter produced by photosynthesis is subsequently remineralized in the water column. Therefore the pattern of $\delta^{13} \mathrm{C}$ of $\Sigma \mathrm{CO}_{2}$ is largely driven by deep-water circulation patterns (Fig. 2; Kroopnick, 1980).

The Ceara Rise is an ideal place to observe changes in the depth distribution of deep-water properties of the Atlantic Ocean because it intersects these water masses over the depth range of 2800-4500 m. The Ceara Rise is an aseismic ridge in the western equatorial Atlantic bearing a thick cover of calcareous ooze with various amounts of ter- rigenous material delivered by the nearby Amazon River. Sites 925, 927, and 929, on which we report here, are drilled in a depth transect at water depths of $3041 \mathrm{~m}, 3315 \mathrm{~m}$, and $4356 \mathrm{~m}$, respectively (Fig. 1; Table 1). At shallower depths, the Ceara Rise is bathed in NADW (Reid, 1989), with a broad transition zone to LCDW between 4200 and $4600 \mathrm{~m}$, in which the deepest site is located (Fig. 2). Because of the proximity of all sites, by comparing only synchronous measurements, the vertical gradients in $\delta^{13} \mathrm{C}$ will largely reflect changes in deep-water hydrography, namely, the depth or strength of gradient between water masses.

\section{MATERIAL AND METHODS}

All sites were sampled at 10 -cm intervals along the composite record for each site, which has been spliced together using magnetic susceptibility and color reflectance core logs of at least three holes of each site during Leg 154 (Curry, Shackleton, Richter, et al., 1995). Usually, $8-10 \mathrm{~cm}^{3}$ bulk sediment have been washed over a $63-\mu \mathrm{m}$ mesh sieve and dried in an oven at $50{ }^{\circ} \mathrm{C}$. Five taxa of benthic foraminifers (predominantly Cibicides wuellerstorfi, to a minor degree Cibicides bradyii, Cibicides cicatricosus, Cibicides kullenbergi, and Nuttalides umbonifera) were picked from the $>250-\mu \mathrm{m}$ size fraction. One or two specimens of these species were analyzed for stable carbon and oxygen isotopic composition using Finnigan MAT 252 micro-mass spectrometers coupled with a Finnigan automated carbonate device at the Woods Hole Oceanographic Institution (all sites, 0$1 \mathrm{Ma}$ ) and at the University of Bremen (all sites, 1-2.6 Ma). The carbonate was reacted with orthophosphoric acid at $75^{\circ} \mathrm{C}$. The reproducibility of the measurements, as referred to an internal carbonate standard in each laboratory, is better than $\pm 0.07 \%$ and $\pm 0.05 \%$ for oxygen and carbon isotopes, respectively. The conversion to the Pee Dee Belemnite scale was performed using the international standards NBS 18, 19, and 20. According to Curry (1996), N. umbonifera values were offset by $-0.2 \%$ or $\delta^{18} \mathrm{O}$ and $+0.2 \%$ or for $\delta^{13} \mathrm{C}$ to make their data equivalent to Cibicides.

\section{AGE MODEL}

The age models developed here for Sites 925 through 929 are defined relative to meters composite depth (mcd). They should be equally applicable to the intervals that define the shipboard splice on the composite-depth scale, assuming all cores analyzed here were correlated accurately by means of magnetic susceptibility and color reflectance to the shipboard spliced records (Curry, Shackleton, Richter, et al., 1995).

Due to the lack of any paleomagnetic reversals, the development of the age models started with the shipboard biostratigraphic data (which were-as we subsequently discovered-mostly within a range of one obliquity cycle around their "true" age). This first step was followed by tuning the composite magnetic susceptibility record of Site 926, which has been chosen to serve as a master record, to variations in orbital parameters. First using the insolation record determined by Berger and Loutre (1991) for July at $65^{\circ} \mathrm{N}$, we switched later to another target record containing the Precession and Obliquity records determined by the 1,1-solution of Laskar (1990) and Laskar et al. (1993) and rescaled to match the Berger-solution using the formula

$$
790 \text { (tilt }-1.2 \text { precession) }+117 \text {. }
$$

Although there is not much difference between the solutions back to about 3 Ma (i.e., less than 2 k.y. up to 2.5 Ma; Lourens et al., 1996), the latter target was chosen for consistency with the age models of the Pliocene and late Miocene age models (Tiedemann and Franz, 


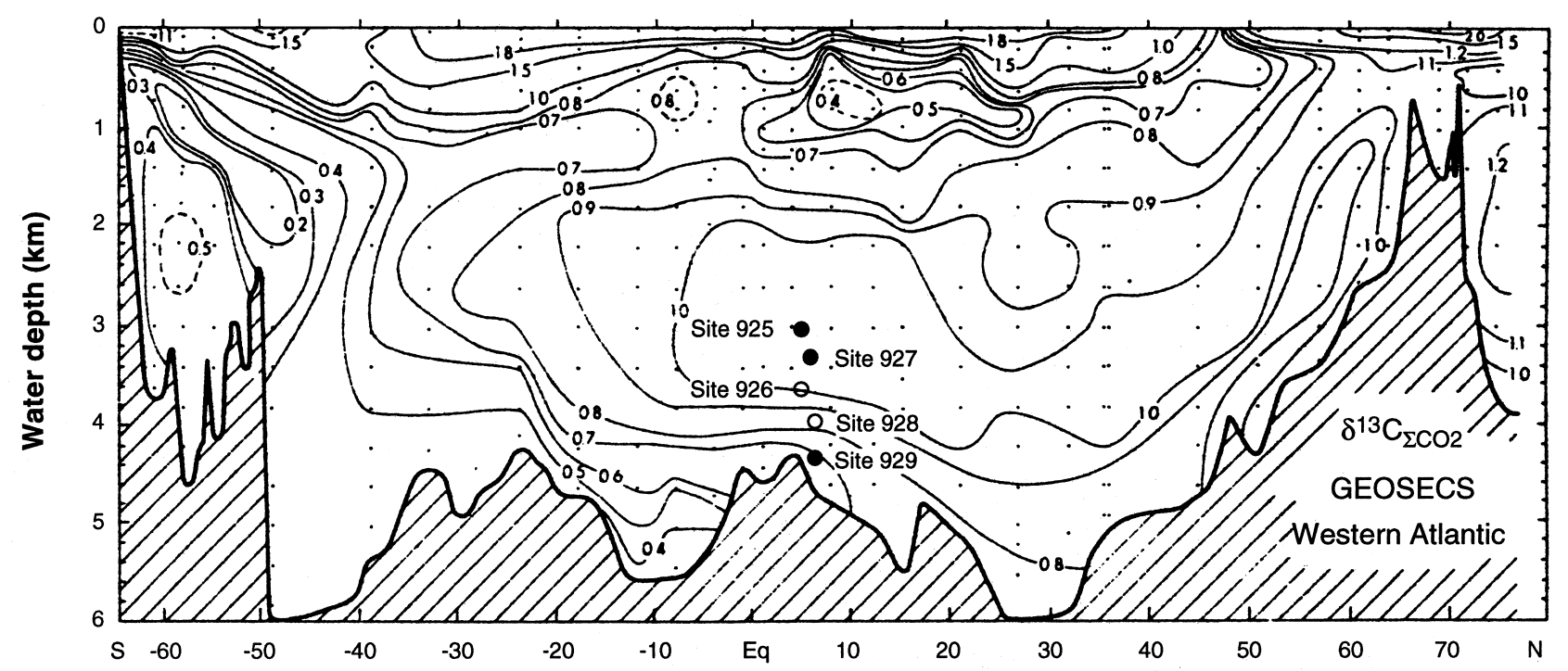

Latitude $\left({ }^{\circ}\right)$

Figure 2. Western Atlantic transect of $\delta^{13} \mathrm{C}$ of $\Sigma \mathrm{CO}_{2}$ from GEOSECS (Kroopnick, 1980). The relative positions of Sites 925 through 929 are indicated as open circles. Solid circles mark sites for which isotope records are presented in this study.

Table 1. Locations and water depth of Leg 154 sites.

\begin{tabular}{cccc}
\hline Site & Latitude & Longitude & $\begin{array}{c}\text { Water depth } \\
(\mathrm{m})\end{array}$ \\
\hline Site 925 & $4^{\circ} 12.2^{\prime} \mathrm{N}$ & $43^{\circ} 29.3^{\prime} \mathrm{W}$ & 3040 \\
Site 926 & $3^{\circ} 43.1^{\prime} \mathrm{N}$ & $42^{\circ} 54.5^{\prime} \mathrm{W}$ & 3598 \\
Site 927 & $5^{\circ} 27.7^{\prime} \mathrm{N}$ & $44^{\circ} 28.8^{\prime} \mathrm{W}$ & 3326 \\
Site 928 & $5^{\circ} 27.3^{\prime} \mathrm{N}$ & $43^{\circ} 44.9^{\prime} \mathrm{W}$ & 4012 \\
Site 929 & $5^{\circ} 58.6^{\prime} \mathrm{N}$ & $4^{\circ} 44.4^{\prime} \mathrm{W}$ & 4369 \\
\hline
\end{tabular}

this volume; Shackleton and Crowhurst, this volume). The fine-tuning was done iteratively by correlating each prominent maximum (in roughly $1-\mathrm{m}$ intervals) of the magnetic susceptibility to the minima of the target record. This gave an age control point for each precession cycle or, if not possible, for at least each obliquity cycle. In a third step, we transferred the obtained age model of Site 926 to all other sites by graphic correlation of their composite susceptibility records to the one of Site 926. This site-by-site correlation was begun during Leg 154 in roughly 5-m intervals and was refined for our purposes and, if necessary, corrected.

We used two independent methods to test our correlation between the susceptibility record and the orbital target. We isolated the obliquity and precession components from the tuned susceptibility records by filtering (41-k.y. filter: 24.4 cycles/m.y., 4.88 cycles/m.y. bandwidth; and 21-k.y. filter: 47.6 cycles/m.y., 9.52 cycles/m.y. bandwidth) and comparing these to changes in orbital obliquity and precession, respectively (Fig. 3). For each filter output from the susceptibility record of Site 926 there is a remarkable similarity to its orbital counterpart, and it is evident that no cycle is missing throughout the tuned interval between 0 and $2.6 \mathrm{Ma}$. Also, the records of Sites 925 , 928, and 929 appeared to be complete. For the record of Site 927, we detected a superfluous cycle between 52.10 and $53.60 \mathrm{mcd}$ (1.298 $\mathrm{Ma})$, and a cycle missing at $91.28 \mathrm{mcd}(2.373-2.409 \mathrm{Ma})$.

We applied the obtained age model for Site 925 to its benthic oxygen isotope record and compared the resulting curve to the tuned benthic record of ODP Sites 677 (Shackleton et al., 1990) and 846 (Shackleton et al., 1995). Cross-spectral analysis between both records shows a significant coherence over the obliquity $(k=0.96)$ and precession frequency bands $(k=0.84)$ with the Site 925 record leading the Pacific record by 2.1 k.y. and 1.7 k.y., respectively. From those phase differences, we determined the phase relationship between magnetic susceptibility and insolation to be in the order of 2 k.y., which has been subtracted from the tuned ages to obtain the final age models (Appendix 1). Cross checks with the $\delta^{18} \mathrm{O}$ records of Sites 927 and 929 confirmed the subtracted phase shift to be correct (Table 2).

All data sets presented in this paper are available via internet from the first author upon request.

\section{RESULTS}

The benthic oxygen and carbon isotope data for the last 2.6 Ma are presented as raw data vs. composite depth in Figure 4, and as a function of time, interpolated in 3-k.y. intervals, in Figure 5. The $\delta^{18} \mathrm{O}$ records exhibit the typical glacial-interglacial changes documenting the growth and decay of the northern hemisphere ice sheets. As is known from many other sites, the cyclicity is dominated by an obliquity-related response for late Pliocene and early Pleistocene times, which changes to a 100-k.y. period dominance in the late Pleistocene, indicating a major influence of ice shield and/or crustal dynamics since about $1 \mathrm{Ma}$ (for a recent discussion see Berger et al., 1995).

The $\delta^{13} \mathrm{C}$ records exhibit glacial-interglacial changes that closely match the oxygen isotope variability. Carbon isotope values are lower at times of ice maxima and higher during warm periods. Most of the $\delta^{13} \mathrm{C}$ variation at all sites occurs at the primary Milankovitch frequencies (Fig. 6). Cross-spectral analyses for the interval 2.6-0 Ma (Table 2) indicate that carbon and oxygen records of each site are coherent in the major orbital bands. But the phases of $\delta^{13} \mathrm{C}$ relative to $\delta^{18} \mathrm{O}$ are not constant. Variations in $\delta^{13} \mathrm{C}$ lead those of $\delta^{18} \mathrm{O}$ at the 100 k.y. period (2.8-4.0 k.y., except for Site 927), are nearly in phase at the 41-k.y. period ( -0.5 to +1.0 k.y.) and lag behind $\delta^{18} \mathrm{O}$ at the $23-$ k.y. period (2.2-5.7 k.y.). Although these are relatively small variations in phase, they are significant, and similar to those found at the western Pacific Site 806 (Bickert et al., in press) and the eastern Pacific Site 849 (Mix et al., 1995). The different phasing of $\delta^{13} \mathrm{C}$ relative 

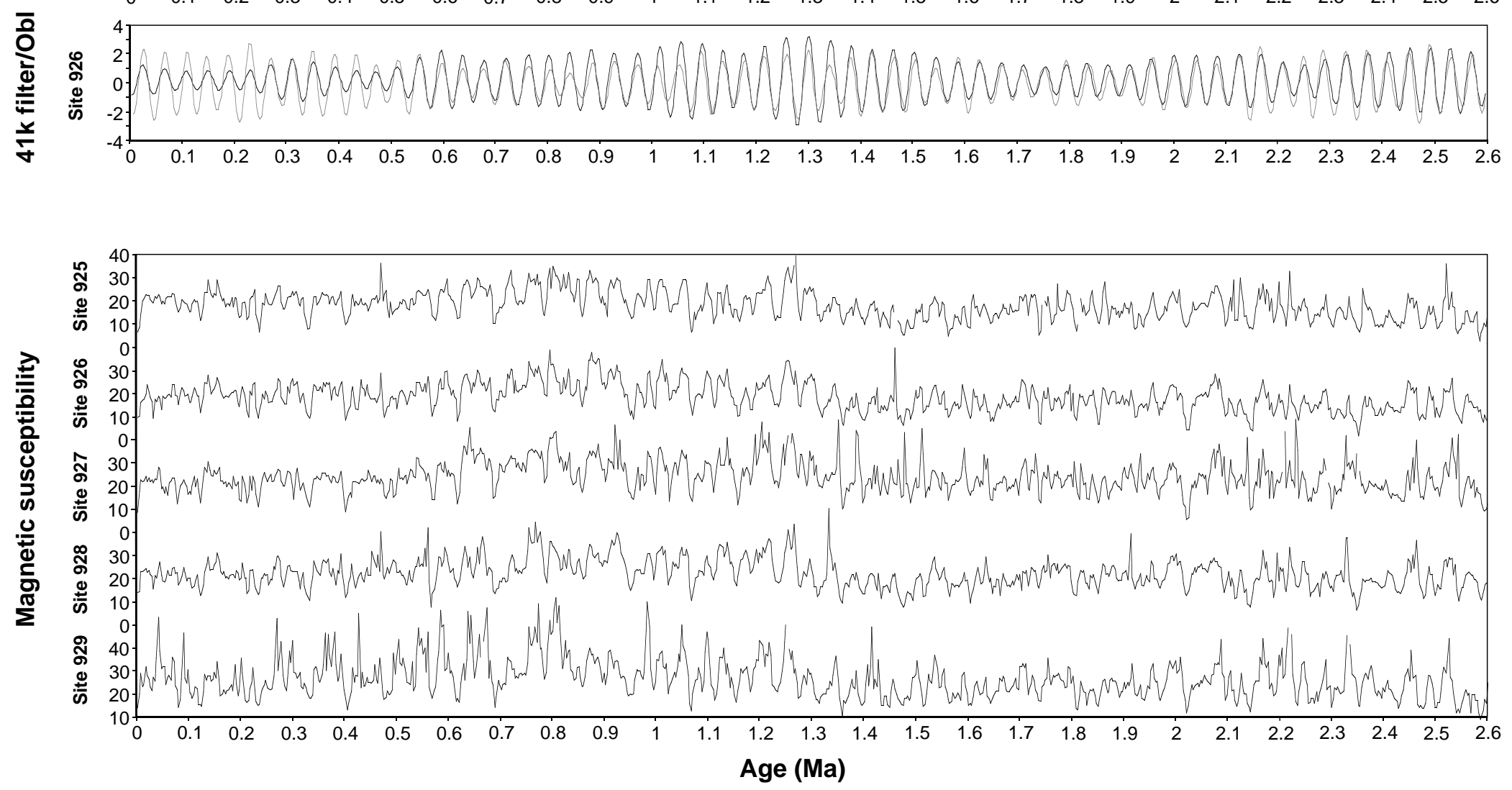

Figure 3. Top: summary of the tuning of Leg 154 sites over the last 2.6 Ma: 21-k.y. and 41-k.y. filter of Site 926 magnetic susceptibility, tuned to the insolation record using the 1,1-solution of Laskar (1990) compared to the orbital precession and obliquity (dotted lines), respectively. Bottom: magnetic susceptibility records of Sites 925 through 929 , mapped to the Site 926 time scale by graphic correlation. 
Table 2. Coherencies (coh) and phase relations ( $\phi$, expressed in radians and k.y.) of Sites 925, 927, and 929 benthic isotope records for the eccentricity, obliquity, and precession frequency bands.

\begin{tabular}{|c|c|c|c|c|c|c|c|c|c|}
\hline \multirow[b]{2}{*}{ Site } & \multicolumn{3}{|c|}{100 k.y. } & \multicolumn{3}{|c|}{41 k.y. } & \multicolumn{3}{|c|}{23 k.y. } \\
\hline & coh & $\phi(\mathrm{rad})$ & $\phi$ (k.y.) & $\mathrm{coh}$ & $\phi(\mathrm{rad})$ & $\phi$ (k.y.) & coh & $\phi(\mathrm{rad})$ & $\phi$ (k.y.) \\
\hline \multicolumn{10}{|c|}{ Benthic $\delta^{18} O$ vs. Sites $677 / 846$ benthic $\delta^{18} O$} \\
\hline 925 & 0.94 & 0.04 & 0.6 & 0.96 & 0.01 & 0.1 & 0.84 & 0.07 & 0.3 \\
\hline 927 & 0.94 & 0.02 & 0.3 & 0.99 & -0.07 & -0.5 & 0.92 & 0.06 & 0.2 \\
\hline 929 & 0.97 & -0.10 & -1.6 & 0.98 & -0.01 & -0.1 & 0.67 & 0.28 & 1.0 \\
\hline \multicolumn{10}{|c|}{ Benthic $\delta^{13} \mathrm{C}$ vs. benthic $\delta^{18} \mathrm{O}$} \\
\hline 925 & 0.85 & 0.18 & 2.9 & 0.93 & -0.07 & -0.5 & 0.70 & -1.55 & -5.7 \\
\hline 927 & 0.92 & -0.01 & -0.2 & 0.94 & -0.07 & -0.5 & 0.85 & 0.94 & -3.4 \\
\hline 929 & 0.77 & 0.25 & 4.0 & 0.92 & 0.16 & 1.0 & 0.70 & -0.60 & -2.2 \\
\hline \multicolumn{10}{|c|}{ Benthic $\Delta \delta^{13} \mathrm{C}_{\text {Atl_-Pac }}$ vs. benthic $\delta^{18} \mathrm{O}$} \\
\hline $925-806$ & $\begin{array}{c}\text { Alt-ipac. } \\
0.57\end{array}$ & 0.92 & 14.6 & 0.79 & -0.18 & -1.2 & (0.49) & $(-1.43)$ & $(-5.2)$ \\
\hline $927-806$ & 0.64 & 0.52 & 8.3 & 0.76 & -0.84 & -5.5 & 0.73 & -0.53 & -1.9 \\
\hline $929-806$ & 0.52 & 0.35 & 11.9 & 0.75 & -0.43 & -2.8 & 0.75 & -0.55 & -2.0 \\
\hline
\end{tabular}

Notes: We analyzed the variability in the frequency domain using the Blackman-Tuckey approach with $50 \%$ lags and at the $80 \%$ confidence level $(\mathrm{k}=0.52)$. Parentheses highlight coherencies below the $80 \%$ confidence level. Positive phasing indicates that changes in a given parameter lead changes in the reference record.

to $\delta^{18} \mathrm{O}$ in the three orbital bands implies that carbon- and ice-systems are but loosely connected, or that, in any case, their interactions are nonlinear to some degree.

However, the amplitude of the glacial-interglacial $\delta^{13} \mathrm{C}$ variations at Site 925 is generally larger in the Pleistocene (about $1.2 \%$ since $1.6 \mathrm{Ma}$ ) than in the interval before (about $0.6 \%$ ). While this pattern is confirmed in the shallow Site 927, the record of the deepest Site 929 exhibits high amplitudes (more than 1.0\%o) throughout the entire time interval (Fig. 5). The interglacial values are thereby close to the values of the shallower sites, but they are always about $0.3 \%$ o lower, exhibiting the modern depth gradient in carbon isotopes at the position of the Ceara Rise (Fig. 2). In contrast, the glacial values are much lower than the values of the shallower site, indicating an increasing depth gradient during cold stages. This is especially true for the time interval between 2.6 and 1.6 Ma. In addition to the glacial-interglacial variability, all carbon isotope records show a superimposed longterm variability with a magnitude of $0.5 \%$ and wave length in the order of 500 k.y. (Fig. 5).

Replicate isotope measurements at all three sites ( $0-1 \mathrm{Ma})$ document that there is a greater internal variability for $\delta^{13} \mathrm{C}$ than for $\delta^{18} \mathrm{O}$. Paired measurements of $\delta^{18} \mathrm{O}$ usually agree to within $0.2 \%$, whereas $\delta^{13} \mathrm{C}$ values exhibit significantly greater variability within a sample up to $0.5 \%$ and sometimes more than $1.0 \%$ (Fig. 4). The variability in $\delta^{13} \mathrm{C}$, but not in $\delta^{18} \mathrm{O}$, exceeds the level one might expect due to various biological processes that occur during the calcification process (Curry, 1996). This suggests that the observed variability in carbon isotopes might reflect real changes in water column chemistry occurring on periods that are less than orbital scale and perhaps closer than time resolution of our records (about $10 \mathrm{~cm}$ sample spacing $=3$ k.y.).

Comparison of individual $\delta^{13} \mathrm{C}$ maxima and minima between the two shallow Sites $925(3041 \mathrm{~m})$ and $927(3315 \mathrm{~m})$ reveals that the carbon isotope records usually agree to within $0.25 \%$ o, except for single peaks with a difference up to $0.5 \%$. Moreover, it is obvious that the Site 927 record has a higher variability as compared with the 925 record, a finding that might be explained by the higher sedimentation rates and therefore higher resolution of Site 927 (36 m/m.y.) as compared with Site 929 (29 m/m.y.). However, the range of the site-bysite differences are well within the internal variability of single samples, emphasizing the value of the depth-transect approach to the Leg 154 sites.

\section{DISCUSSION}

\section{$\delta^{13}$ C-Gradients: Western and Eastern Equatorial Atlantic}

For comparison of carbon isotope records of about the same water depth in the western and eastern equatorial Atlantic, we chose the benthic record of ODP Site $659\left(18^{\circ} 05^{\prime} \mathrm{N}, 21^{\circ} 02^{`} \mathrm{~W}, 3070 \mathrm{~m}\right.$ water depth), which is located on top of the Cape Verde Plateau off northwest Africa (Tiedemann, 1991). The stable isotopes have been measured on $C$. wuellerstorfi. The age model down to $2.85 \mathrm{Ma}$ is based on graphic correlation of the benthic oxygen isotope record with the record of Site 677 (Tiedemann et al., 1994). Therefore, the Atlantic record is directly comparable to the records of the Ceara Rise. The sample spacing of the Site 659 record is about $4.3 \mathrm{k} . \mathrm{y}$., which gives a somewhat lower time resolution than the one from Site 925 (3.4 k.y.). For correlation purposes, we linearly interpolated the raw data of each site in the time domain to 3-k.y. intervals and smoothed the resulting curves using a 5-point running average to avoid artificially high-frequency noise while correlating. This smoothing effectively removed variations with a wavelength less than 15 k.y., but it preserved the signal in the primary orbital bands of $19 \mathrm{k} . \mathrm{y}$. and longer.

The carbon isotope records from Sites 925 and 659 are shown in Figure 7 as a function of age, after interpolation and smoothing as noted above. The records share many similarities, but they are not identical. Over most of the record, the interglacial $\delta^{13} \mathrm{C}$ values from Site 659 are significantly lower than those from Site 925, with slightly increasing differences from $0.3 \%$ during the Pliocene to $0.4 \%$ in the late Pleistocene. These differences are consistent with the modern $\delta^{13} \mathrm{C}$ gradient between the western and the eastern Atlantic, according to the modern hydrographic asymmetry in deep-water distribution. Whereas the main part of NADW, well oxygenated and enriched in ${ }^{13} \mathrm{C}$, known as the "western boundary current," flows in the western Atlantic to the south, the slower and older eastern branch of the $\mathrm{NADW}$, therefore slightly depleted in oxygen and ${ }^{13} \mathrm{C}$, flows in general also to the south but is partly recirculated in the eastern basins (Kroopnick, 1985; Reid, 1989). Although Site 659 is located close to the African coast, it is not influenced by the high productive upwelling system off northwest Africa. This is documented by the very low contents in total organic carbon (TOC) of $0.05-0.4 \mathrm{wt} \%$ and low TOC-accumulation rates between 0.02 and $0.1 \mathrm{~g} / \mathrm{m}^{2} / \mathrm{yr}$ (Tiedemann, 1991). A "Mackensen-effect" (Mackensen et al., 1993) on the $\delta^{13} \mathrm{C}$ values of Cibicides as an explanation of the west-east Atlantic gradients is therefore rather unlikely.

Since about 1.6 Ma, the glacial $\delta^{13} \mathrm{C}$ values of Sites 925 and 659 are usually similar, suggesting more similar deep-water properties during those Pleistocene stages by the reduced production of NADW and the subsequent volumetric increase of southern water masses as proposed by many authors (Curry et al., 1988; Duplessy et al., 1988; Oppo and Fairbanks, 1987; Oppo et al., 1990; Sarnthein et al., 1994; Bickert and Wefer, 1996; Curry, 1996). This result is consistent with the pattern observed in carbonate dissolution records, which reveals the same levelling of western and eastern bottom water properties in glacial times (Bickert and Wefer, 1996). 

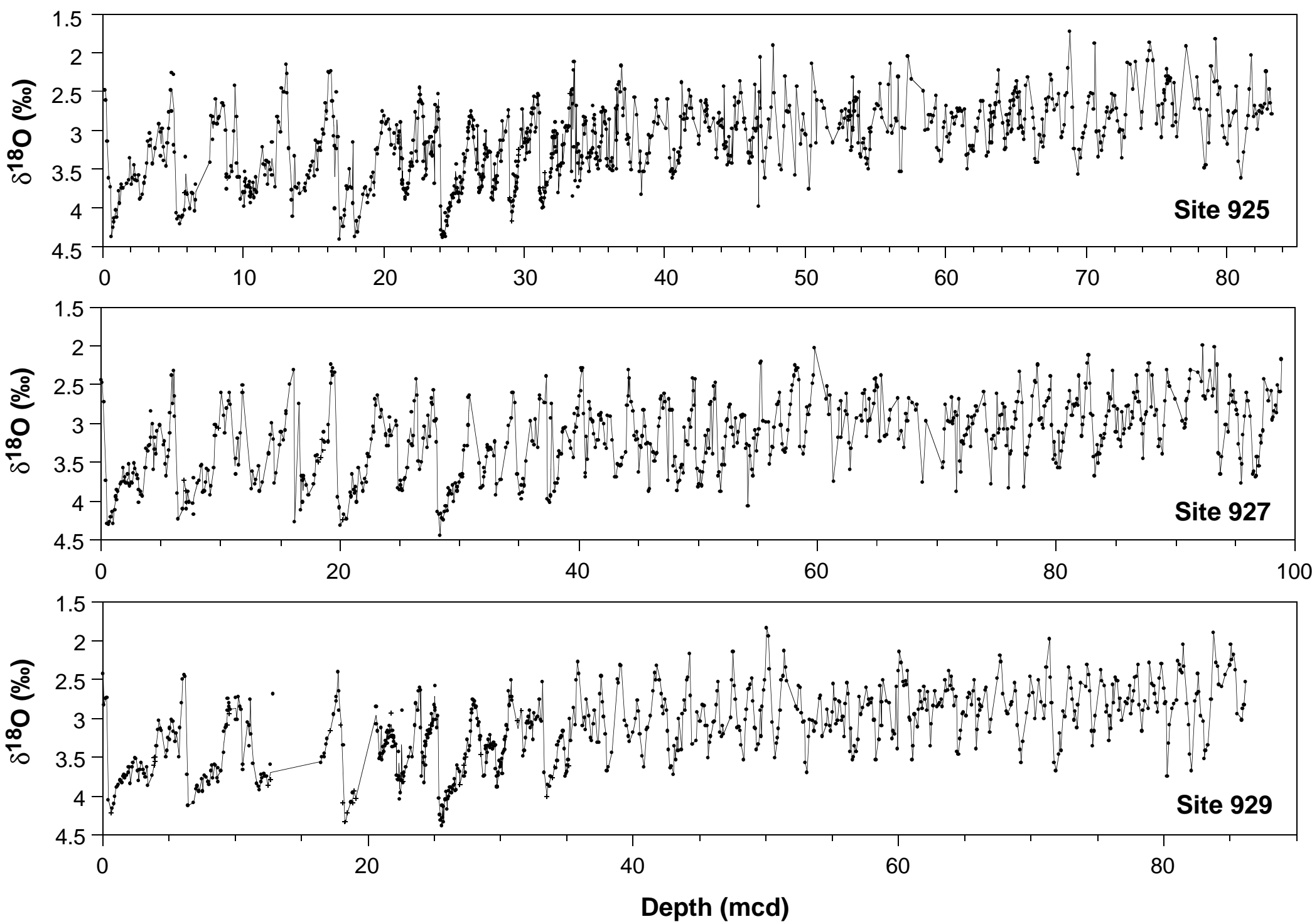

Figure 4. Oxygen and carbon isotope measurements for Sites 925, 927, and 929, measured on Cibicides wuellerstorfi, Cibicides spp. (both indicated by black circles), and Nuttalides umbonifer (crosses) vs. composite depth. $N$. umbonifera values were offset by $-0.2 \%$ for $\delta^{18} \mathrm{O}$ and $+0.2 \%$ for $\delta^{13} \mathrm{C}$ to make their data equivalent to Cibicides. The lines trace the average values at each depth level. 

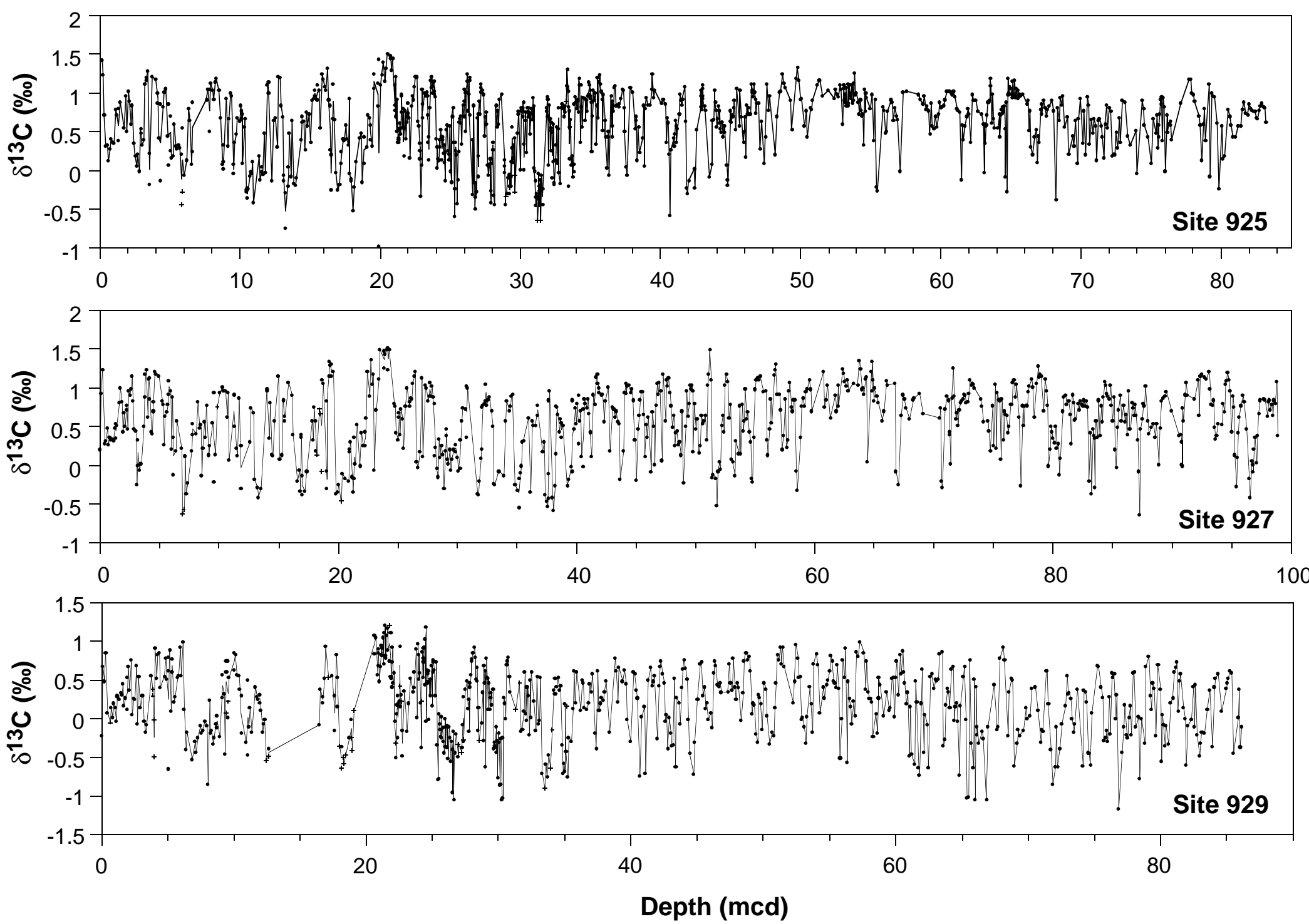

Figure 4 (continued). 

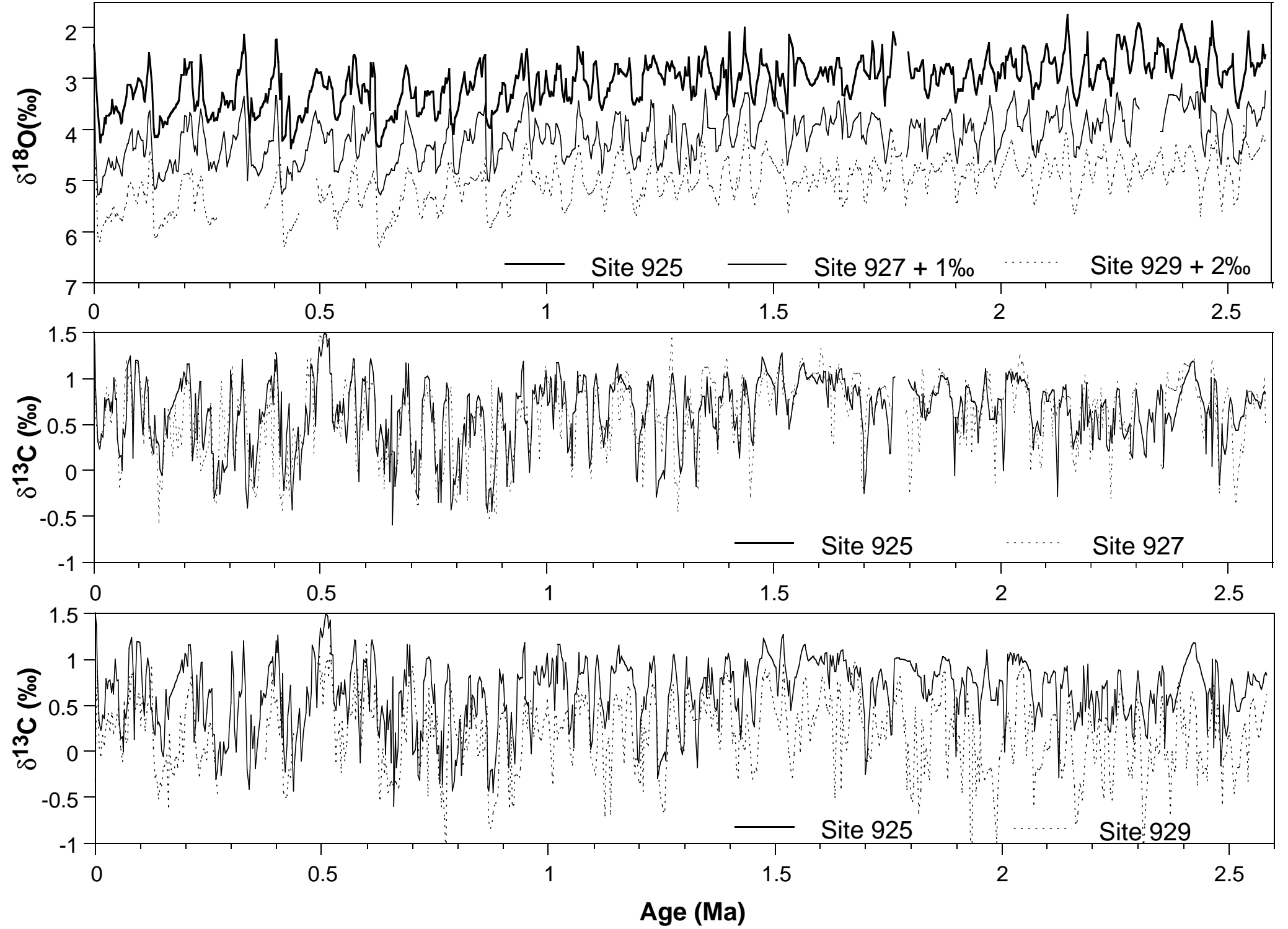

Figure 5. Oxygen and carbon isotope measurements for Sites 925, 927, and 929, measured on Cibicides wuellerstorfi, Cibicides spp., and Nuttalides umbonifera., interpolated to 3-k.y. sample spacing. 

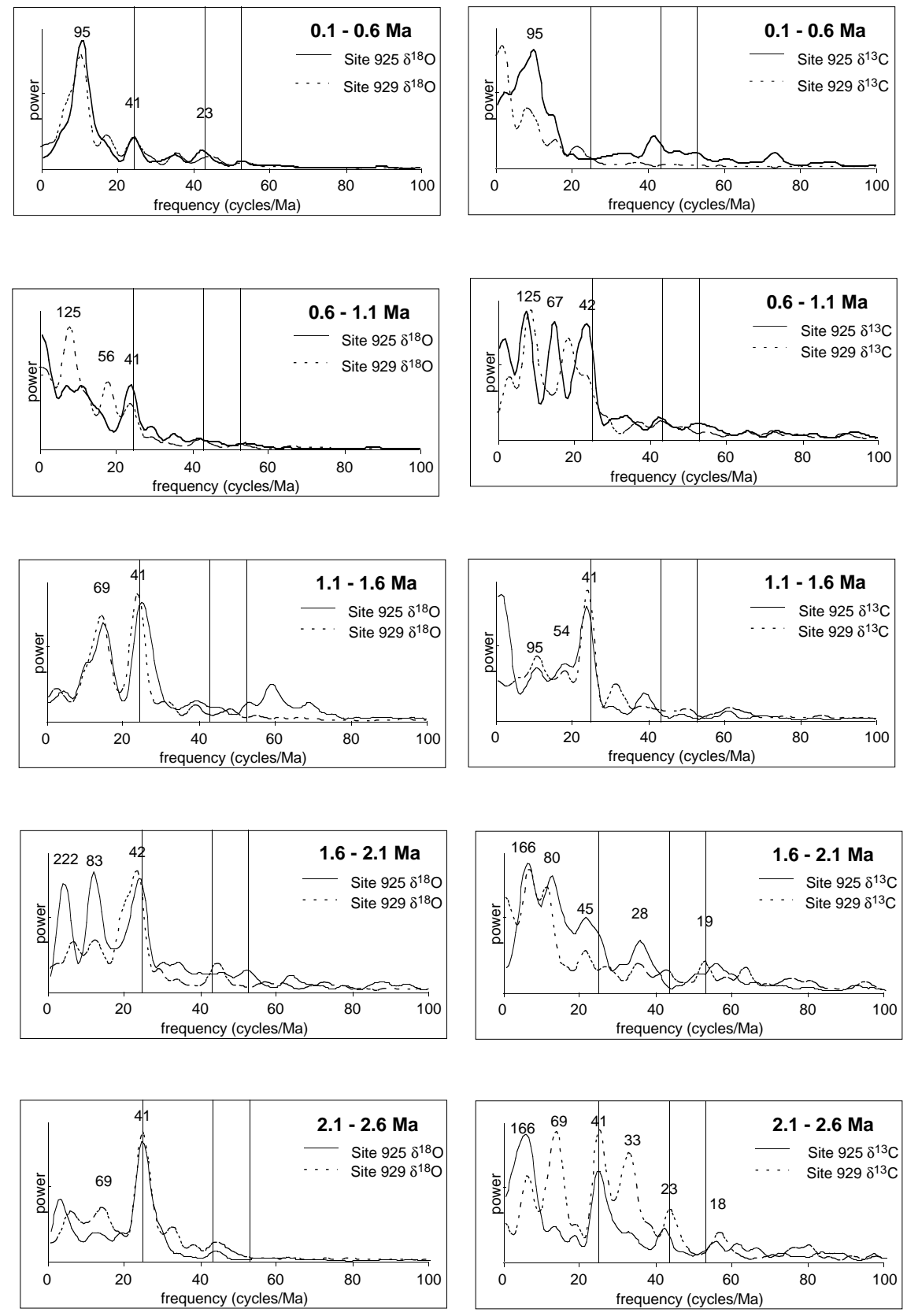

Figure 6. Evolutionary power spectra comparing the $\delta^{18} \mathrm{O}$ and $\delta^{13} \mathrm{C}$ records of Sites 925 and 929 from 0.1 to $2.6 \mathrm{Ma}$ in 0.5 -Ma windows.

\section{$\delta^{13} \mathrm{C}-$ Gradients: Western and Northern Atlantic}

A further constraint on past variability of deep-ocean circulation comes from comparing the western Atlantic $\delta^{13} \mathrm{C}$ record from Site 925 with the North Atlantic Site 607 (Raymo et al., 1990). At this site, a high resolution isotope record of $C$. wuellerstorfi is available for the interval from 0.24 to $3.5 \mathrm{Ma}$ (including the additions by Raymo et al., 1992). The record from the nearby piston Core V30-97, analyzed by Mix and Fairbanks (1985), which is normally used to substitute the missing late Pleistocene interval, is not discussed here, because it contains analyses from the genus Uvigerina, which is known to give different results - especially in $\delta^{13} \mathrm{C}$-due to its endobenthic way of life (Zahn et al., 1986). To make the comparison between the West and the North Atlantic, we placed the Site 607 record on the same time scale as the Sites 677 and 846 by graphic correlation of the oxygen isotope curves and used the same interpolating and smooth- ing routines described above. The revised time scale for Site 607 is tabulated in Appendix 2.

Figure 8 illustrates the smoothed $\delta^{13} \mathrm{C}$ isotope records from Sites 607 and 925 on the Site 925 time scale. The two records appear highly coherent, but are not identical. During the late Pliocene and the earliest Pleistocene up to $1.6 \mathrm{Ma}$ the interglacial $\delta^{13} \mathrm{C}$ values of the North Atlantic site are about $0.25 \%$ o higher as compared with the equatorial site values. Although these differences are small and within the internal variability of individual samples, as described above, these differences are significant and might be attributed to the normal gradient along the flow path of the NADW, because Site 607 at $41^{\circ} \mathrm{N}$ is located much closer to the source area of this deep-water mass as compared with Site 925 at $4^{\circ} \mathrm{N}$. During glacial stages up to $1.6 \mathrm{Ma}$, the carbon isotope records of the two sites exhibit similar values. In agreement with the observations of the west/east equatorial gradients, the entire deep Atlantic seems to be filled with a homogenous deep- 


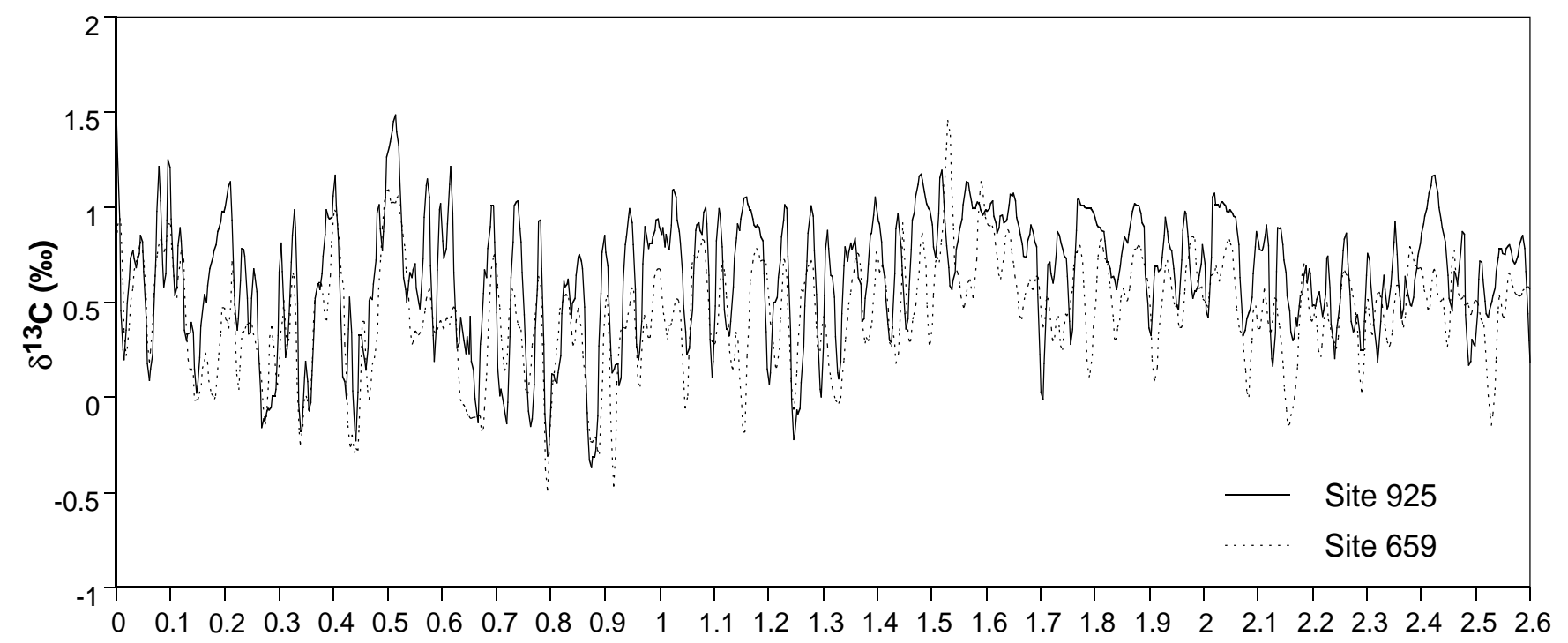

Age (Ma)

Figure 7. Carbon isotope records from western equatorial Atlantic Site 925 (this study) and eastern equatorial Atlantic Site 659 (Tiedemann, 1991), interpolated to 3-k.y. sample spacing and smoothed with a 5-point running average.

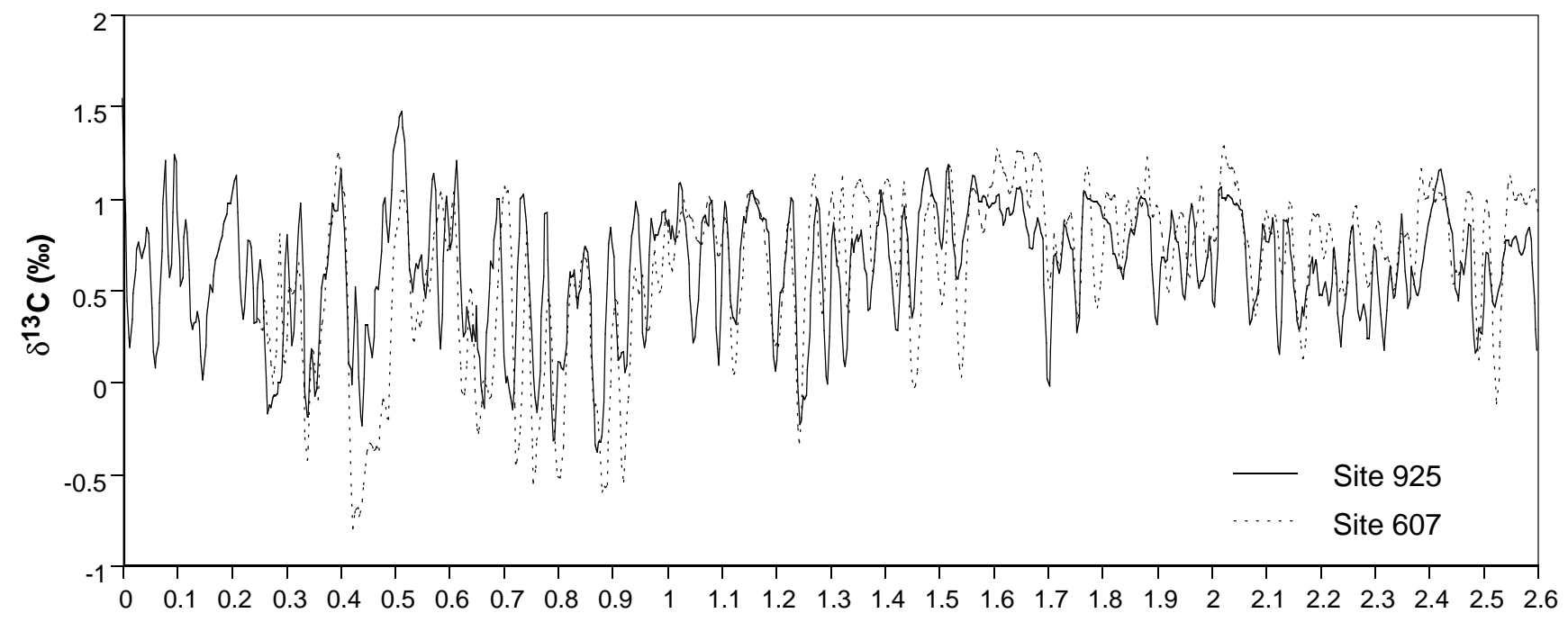

Age (Ma)

Figure 8. Carbon isotope records from western equatorial Atlantic Site 925 (this study) and northern Atlantic Site 607 (Raymo et al., 1990), interpolated to 3k.y. sample spacing and smoothed with a 5-point running average.

water mass. The absence of any $\delta^{13} \mathrm{C}$ gradients in the $3000-3500 \mathrm{~m}$ ocean layer reveals that the exchange rates for this glacial deep water was low compared to the fluxes observed in NADW today (about 20 Sverdrups; Reid, 1989).

From 1.6 Ma on, there is a change in the inter-site differences. The interglacial differences decrease to about zero, whereas the glacial differences increase up to $0.7 \%$ in the late Pleistocene, with the North Atlantic record depleted in ${ }^{13} \mathrm{C}$ relative to the equatorial record. The question arises whether this gradient is a function of the distance to the source area of the glacial deep water or of its depth distribution. To ensure this, we examined the results of benthic isotope measure- ments of the piston Core EW9209-2JPC $\left(5^{\circ} 38^{\prime} \mathrm{N}, 44^{\circ} 28^{\prime} \mathrm{W}, 3528 \mathrm{~m}\right.$; Curry, 1996), which is located on the Ceara Rise only 10 nautical miles to the north of Site 927, but deeper than this site and in about the same water depth as Site 607 . This core exhibits similar values to Site 607 during the late Pleistocene. This suggests that there must have been a strong gradient in $\delta^{13} \mathrm{C}$ between 3000 and $3500 \mathrm{~m}$ water depth, which may have been related to the mixing zone between a glacial northern component water above and a glacial southern component water below. Duplessy et al. (1988) mapped a glacial deep water, produced in the North Atlantic and enriched in ${ }^{13} \mathrm{C}$, which Imbrie et al. $(1992,1993)$ defined as the upper branch of the NADW 
(the "boreal" heat pump) and which was similar or even increasingly produced during glacials compared with today, while the lower branch of NADW remained suppressed. Sarnthein et al. (1994), in their detailed East Atlantic section for the last glacial maximum (LGM, 21.5-23.5 ka), found a strong gradient in $\delta^{13} \mathrm{C}$ around $3500 \mathrm{~m}$ water depth extending from about $50^{\circ} \mathrm{N}$ to the equator. Curry and Lohmann (1990) and Bickert and Wefer (1996) showed that this glacial gradient between 3000 and $4000 \mathrm{~m}$ water also existed in the western Atlantic basins and that the asymmetry in bottom water distribution present today (NADW in the eastern basins, LCDW in the western basins) was absent during the LGM and also in older glacial stages back to about $400 \mathrm{ka}$. The comparison of Sites 925 and 607 records reveal that this glacial pattern can be traced back to at least Stage 22 (about 0.8 m.y. ago) and started to develop at about 1.6 Ma. The absence of any glacial $\delta^{13} \mathrm{C}$ gradient over this depth interval before 1.6 Ma indicates that the boundary between northern and southern component water masses must have lain above or below that depth range.

Thus, the intersite comparison between the northern and the equatorial sites reveals that Site 607, despite its position close to the source of NADW, does provide a reliable recorder of the late Neogene history of the mid-depth Atlantic deep-water circulation.

\section{$\delta^{13}$ C-Gradients: Western Equatorial Atlantic vs. Western Equatorial Pacific}

The last constraint on past deep-water variability comes from comparing the western equatorial Atlantic records from Sites 925 and 929 with a record from the western equatorial Pacific. At ODP Site 806 , which was drilled on the Ontong Java Plateau $\left(0^{\circ} \mathrm{N}, 159^{\circ} \mathrm{E}, 2520\right.$ $\mathrm{m})$ and which is bathed today in Pacific Deep Water, a $C$. wuellerstorfi record is available back to about $4 \mathrm{Ma}$ with a time resolution of about 5 k.y. (Bickert et al., in press). The age model is based on graphic correlation of the benthic oxygen isotope record with the record of Sites 677 and 846 (Shackleton et al., 1990, 1995) and therefore directly comparable with the records of the Ceara Rise. Consistent with the treatment of other data here, we interpolated and smoothed the carbon isotope record for the comparison with the other data sets. As mentioned above, we preferred to use Site $806 \delta^{13} \mathrm{C}$ records as a Pacific deep-water reference because the eastern Pacific ODP Site 677 record was shown to reflect additional local variations in low- $\delta^{13} \mathrm{C}$ organic matter contributing to $\Sigma \mathrm{CO}_{2}$ in the relatively isolated Panama Basin (Mix et al., 1995; Bickert et al., in press).

Figure 9 illustrates the $\delta^{13} \mathrm{C}$ records from western Atlantic Sites 925 and 929 and the western Pacific Site 806. The three $\delta^{13} \mathrm{C}$ records are significantly different from each other. The Pacific site almost always has $\delta^{13} \mathrm{C}$ values lower than the two Atlantic sites, consistent with earlier studies. The deeper Atlantic Site 929 values vary between the shallower Site 925 values during interglacials and the Site 806 values during glacials. For interglacials, a difference of $0.3 \%$ o between the western equatorial sites exhibits the modern pattern of admixing of LCDW to the overlying NADW. During glacials, carbon isotope values of these sites differ by up to $1.0 \%$ but converge since 1.6 Ma.

Comparing the long-term trends of the interglacial values of Sites 925 and 806, the two records show a divergence of the Atlantic and Pacific values from $0.8 \%$ at $2.6 \mathrm{Ma}$ to $1.2 \%$ in the latest Pleistocene. The $\Delta \delta^{13} \mathrm{C}_{\text {Atl-Pac }}$ record of these two sites exhibits maximum gradients up to $1.4 \%$ o during the last 1 m.y. (Fig. 9). This contradicts the results of Mix et al. (1995), who used Site 607 as the Atlantic representative and Site 849 as the Pacific reference. They calculated a decrease in the interglacial differences from $1.1 \%$ in the late Pliocene to 0.8 $1.0 \%$ in the late Pleistocene with a maximum in interocean carbon isotope gradients between 2.1 and 1.3 Ma. These differences in observations may result from the slightly decreasing values of Site 607 relative to those of Site 925 (as noted above) and in the slightly in- creasing values of Site 849 relative to those of Site 806 . The mean ocean $\delta^{13} \mathrm{C}$ value, as it is best presented by Site 806 in the western equatorial Pacific, appears to have remained constant, aside from the long-term variability superimposed on constant mean values (see above). This indicates that the average nutrient content of the world's oceans has been nearly constant despite the dramatic changes in earth climate during the intensification of the Northern Hemisphere glaciation since $2.6 \mathrm{Ma}$. An increase in the interoceanic contrast towards the Pleistocene, as shown in our data, is accompanied by an increase in northern source water $\delta^{13} \mathrm{C}$ values at least over the past $1.5 \mathrm{Ma}$ (Jansen et al., 1988). Oppo et al. (1995), who found a similar increase in the mid-depth tropical Atlantic (Caribbean Sea, Site 502) $\delta^{13} \mathrm{C}$ relative to the mean ocean values, proposed and discussed several hypotheses for this phenomenon. As the most likely mechanism, a nutrient inventory increase is assumed, which was balanced by a nonnutrient-related whole ocean $\delta^{13} \mathrm{C}$ increase such as might occur due to the growth of terrestrial biosphere, to a reduction of $\delta^{13} \mathrm{C}$ values or $\mathrm{C} / \mathrm{P}$ ratios of buried organic matter, or to an increase in the weathering of carbonates relative to organic matter.

Comparing the short-term variability of the carbon isotope records of the Ceara Rise with that of Site 806, the evolution of Atlantic to Pacific carbon isotope gradients was different for each depth level in the western equatorial Atlantic. From 2.6 to 1.6 Ma, at the shallow Site 925 , glacial reductions in $\delta^{13} \mathrm{C}$ were less than those observed between 1.6 and $0 \mathrm{Ma}$. During the late Pleistocene $(0.7-0.3$ $\mathrm{Ma})$, glacial carbon isotope values of even the shallower Atlantic cores were indistinguishable from Pacific values from approximately the same depth. These findings are similar to those described by Raymo et al. (1990), who attributed the glacial $\delta^{13} \mathrm{C}$ decrease to a reduced production of NADW. Using the deep Site 929 record for estimating the evolution of interoceanic $\delta^{13} \mathrm{C}$ gradients would result in a completely different pattern. During the entire interval between 2.6 and 0 $\mathrm{Ma}$, the glacial values resembled or were even lower than the Pacific end-member values, indicating an increased volume of southern component water in the deep equatorial Atlantic. From this pattern we conclude that glacial reductions in NADW started much earlier than previously thought and persisted throughout the past 2.6 Ma. Nevertheless, during the late Pliocene, reductions in NADW were less severe than during the Pleistocene, and the southern component water rose only to a level just above the water depth of Site 929 (4356 $\mathrm{m})$, well below the water depth of Site 925 (3040 m). Since 1.6 Ma, the mixing zone between northern and southern component water in the western Atlantic rose to its late Pleistocene level of about $3500 \mathrm{~m}$ and reached the shallowest depth of about $3000 \mathrm{~m}$ during 0.7 and 0.3 Ma. The interglacial values exhibited always the modern pattern of admixing of LCDW to the overlying NADW.

The fact that glacial $\delta^{13} \mathrm{C}$ values of the deep Site 929 were often lower than the values of the Pacific end member raises the question of whether this event was due to deep-water recirculation, "Mackensen effects," or to the different resolution of the records. Whereas deep-water recirculation was previously assumed to explain lower glacial $\delta^{13} \mathrm{C}$ in the deep Atlantic compared to the glacial Pacific values in the late Pleistocene (Oppo and Fairbanks, 1987), it is now widely accepted that there was no change in the direction of deepocean circulation during glacials. $\mathrm{Cd} / \mathrm{Ca}$ records from cores in the Atlantic as well as in the Pacific do not reveal any inverse gradient between the two oceans (Oppo and Rosenthal, 1994), and the low $\delta^{13} \mathrm{C}$ in the deep Atlantic cores have been shown to be due to respiration of organic matter decreasing the $\delta^{13} \mathrm{C}$ values of even epibenthic foraminifers (Bickert and Wefer, 1996). Such a "Mackensen effect" (Mackensen et al., 1993) on the $\delta^{13} \mathrm{C}$ values of Cibicides as an explanation of the inverse Atlantic-Pacific gradients is also rather unlikely due to the very low contents in total organic carbon (TOC) of 0.05 to $0.3 \mathrm{wt} \%$ in this low-productive area of the western equatorial Atlantic (see also Bickert et al., this volume). The most likely explanation, therefore, might be the much higher resolution of the Site 929 record 

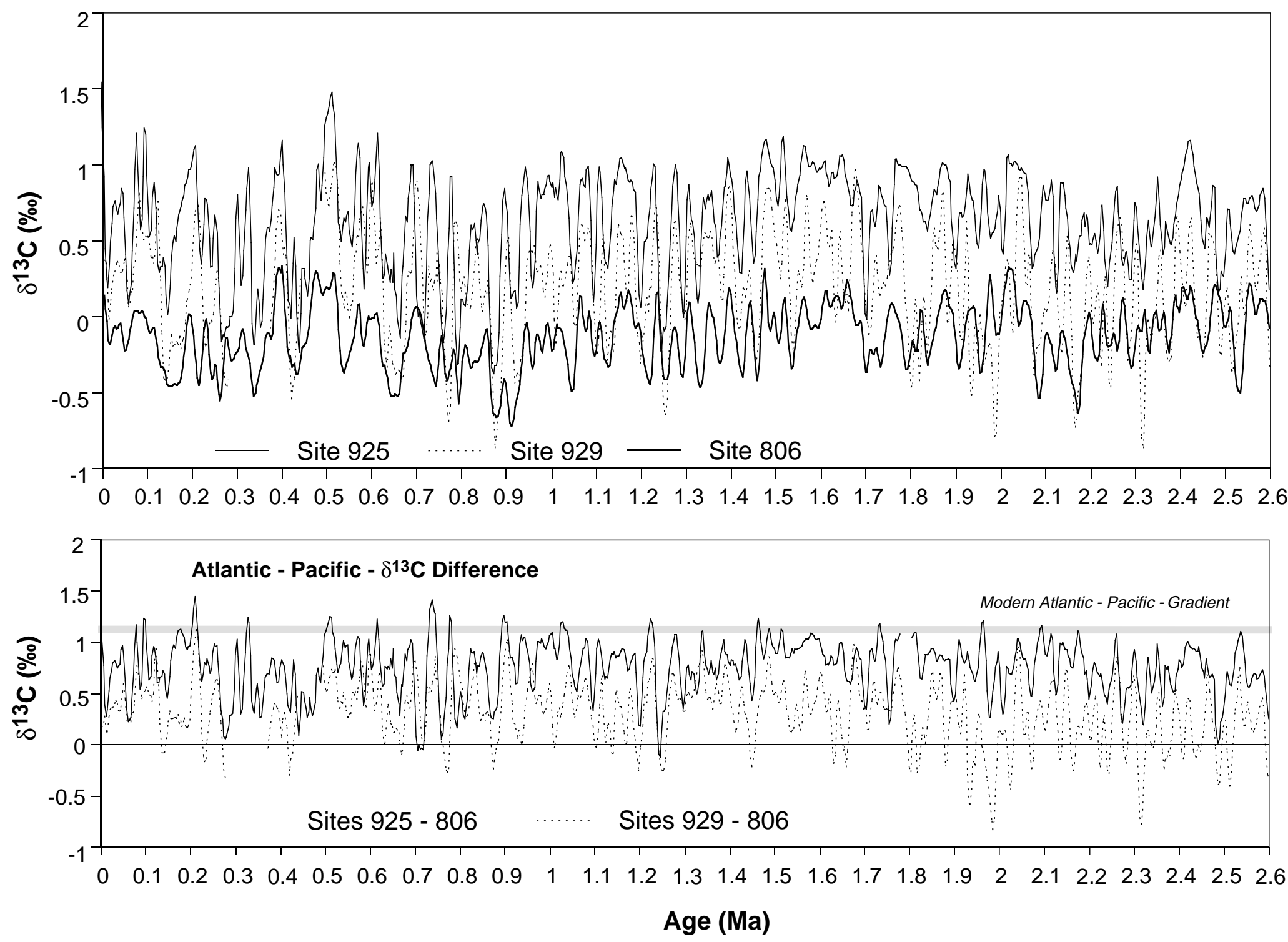

Figure 9. Carbon isotope records from western equatorial Atlantic Sites 925 and 929 compared to western equatorial Pacific Site 806 (Bickert et al., in press), all interpolated to 3-k.y. sample spacing and smoothed with a 5-point running average. The lower panel shows the $\Delta \delta^{13} \mathrm{C}_{\mathrm{Atl}-\mathrm{Pac}}$ of Sites 925 and 929 using the Site 806 record as the Pacific Deep Water end member. The horizontal solid line marks the modern $\delta^{13} \mathrm{C}$ difference between the locations of Sites 925 and 806. 
(3.3 k.y.) compared to the lower resolution of the Site 806 record (5 k.y.). This suggests that the observed variability in carbon isotopes might reflect real changes in water column chemistry occurring on periods that are less than orbital scale and perhaps even closer than time resolution of western Atlantic records.

Cross-spectral analyses for the interval 2.6-0 Ma indicate that Atlantic-Pacific $\delta^{13} \mathrm{C}$ differences, calculated for each site of the Ceara Rise vs. Site 806 , and the $\delta^{18} \mathrm{O}$ of each site are mostly coherent in the major orbital bands (Table 2). But like the phases for $\delta^{13} \mathrm{C}$ itself, the phases of $\Delta \delta^{13} \mathrm{C}$ relative to $\delta^{18} \mathrm{O}$ are not constant. Variations in $\Delta \delta^{13} \mathrm{C}$ lead those of $\delta^{18} \mathrm{O}$ at the 100-k.y. period (8.3-14.6 k.y.), and lag behind $\delta^{18} \mathrm{O}$ at the 41-k.y. period (1.2-5.5 k.y.) and at the 23-k.y. period (1.9-5.2 k.y.). Again, these are relatively small variations in phase, but they are significant, except for the phasing at the precessional period of Site 925 . These new phase relationships agree only partly with earlier results from the deep Atlantic. Like the North Atlantic record from DSDP Site 607, our records lag ice volume in the obliquity and in the precession band, but they do not lag ice volume at the eccentricity band. Therefore, they also partly contradict the Imbrie et al. (1992) model of the deep water-climate link, which postulates changes in deep-water production to lead changes in ice volume at all periods of orbital geometry. Finally, the phase relationships presented here agree with the Cd/Ca record of Oppo and Rosenthal (1994) only for the 100-k.y. band. This implies that the $\mathrm{Cd} / \mathrm{Ca}$ and $\Delta \delta^{13} \mathrm{C}$, two widely used proxies for deep-water reconstructions, have variability in the deep Atlantic that is uncoupled to nutrient variations (Oppo and Rosenthal, 1994). They may be complicated by gas exchange processes at the surface (Broecker and Maier-Reimer, 1992; Charles et al., 1993), by variations in the stoichiometry of organic matter production (Goericke and Fry, 1994), or by variations in the oceanic budget for Cd (Oppo and Rosenthal, 1994).

\section{CONCLUSIONS}

$\delta^{13} \mathrm{C}$ records of the epibenthic foraminifers $C$. wuellerstorfi, Cibicides spp., and N. umbonifera from ODP Sites 925, 927, and 929 were used to reconstruct the history of deep-water circulation in the western equatorial Atlantic. The sites were drilled during Leg 154 at the northeast slope of Ceara Rise in a depth transect between 3040 and $4370 \mathrm{~m}$. The records comprise the time interval from 2.6 to $0 \mathrm{Ma}$. Dating is based on tuning variations of the magnetic susceptibility records to orbital parameters using the 1,1 solution of Laskar.

The $\delta^{18} \mathrm{O}$ records of all sites compare well with other long $\delta^{18} \mathrm{O}$ data sets, including Site 677 of the Panama Basin, which was used as a reference chronology to check the reliability of the susceptibility tuning. Carbon isotope records show a varying depth gradient during the studied period. For interglacials, a difference of $0.3 \%$ oxhibits the modern pattern of admixing of LCDW to the overlying NADW. During glacials, carbon isotope values of shallow and deep sites are different up to $1.0 \%$, but they converge since $1.6 \mathrm{Ma}$, and especially since 1.0 Ma.

The comparison of the western equatorial sites to the eastern Atlantic Site 659 reveals that the interglacial $\delta^{13} \mathrm{C}$ values from Site 659 are significantly lower than those from Site 925, consistent with the modern $\delta^{13} \mathrm{C}$ gradient between the western and the eastern Atlantic, according to the modern hydrographic asymmetry in deep-water distribution. During glacial times, the $\delta^{13} \mathrm{C}$ records of Sites 925 and 659 are mostly identical since 1.6 Ma, suggesting an equalizing in deepwater properties during those Pleistocene stages by the reduced production of NADW and the subsequent volumetric increase of southern water masses.

The $\delta^{13} \mathrm{C}$ gradients between the Ceara Rise transect and the North Atlantic Site 607 indicate the previous published site to be a reliable recorder of the NADW variations, but only for its distinct depth level. Strong gradients during glaciations, especially in the late Pleistocene, give evidence for an upward and downward movement of the mixing zone between northern and southern component water masses.

The evolution of Atlantic-Pacific carbon isotope gradients is examined using a record of the western equatorial Pacific ODP Site $806 \mathrm{~B}(2520 \mathrm{~m})$. From 2.6 to $1.6 \mathrm{Ma}$, glacial reductions in NADW are less than those observed between 1.6 and $0 \mathrm{Ma}$. During the late Pleistocene (0.7-0.3 Ma), glacial carbon isotope values of even the shallower Atlantic cores are indistinguishable from Pacific values from approximately the same depth, indicating the shallowest position of the NADW/LCDW transition since 2.6 Ma. The divergence of the average Atlantic and Pacific values from $0.8 \%$ at $2.6 \mathrm{Ma}$ to $1.2 \%$ in the latest Pleistocene is apparently not due to a mean ocean $\delta^{13} \mathrm{C}$ rise, but might be attributed to an increase in the $\delta^{13} \mathrm{C}$ values of the northern source waters during the history of Northern Hemisphere glaciation.

\section{ACKNOWLEDGMENTS}

We thank the crew and scientific party of Leg 154 for a successful venture at sea, and ODP for samples. We are indebted to Monika Segl, who carefully supervises the operation of the mass spectrometers of the Fachbereich Geowissenschaften, University of Bremen. We thank Ralph Tiedemann for providing data from Site 659 and for fruitful interactions during the last $3 \mathrm{yr}$. Our paper benefited from detailed reviews by Tim Bralower, Alan Mix, and Delia Oppo. We acknowledge financial support from the NSF (OCE 9116303) and the Deutsche Forschungsgemeinschaft (We 992/18).

\section{REFERENCES}

Berger, A., and Loutre, M.F., 1991. Insolation values for the climate of the last 10 million years. Quat. Sci. Rev., 10:297-317.

Berger, W.H., Bickert, T., Takayama, T., Wefer, G., and Yasuda, M., 1995. Quaternary time-scale for Ontong Java Plateau: Milankovitch template for Ocean Drilling Program Site 806. Geology, 22:463-467.

Bickert, T., Berger, W.H., and Wefer, G., in press. The deep western equatorial Pacific in Quaternary times: results from Leg 130 (Ontong Java Plateau). Paleoceanography.

Bickert, T., and Wefer, G., 1996. Late Quaternary deep-water circulation in the South Atlantic: reconstruction from carbonate dissolution and benthic stable isotopes. In Wefer, G., Berger, W.H., Siedler, G. (Eds.), The South Atlantic: Present and Past Circulation: Berlin (Springer), 599-620.

Boyle, E.A., 1988. The role of vertical chemical fractionation in controlling late Quaternary atmospheric carbon dioxide. J. Geophys. Res., 93:15701-15714.

Broecker, W.S., and Denton, G.H., 1989. The role of ocean-atmosphere reorganization in glacial cycles. Geochim. Cosmochim. Acta, 53:2465-2501.

Broecker, W.S., and Maier-Reimer, E., 1992. The influence of air and sea exchange on the carbon isotope distribution in the sea. Global Biogeochem. Cycles, 6:315-320.

Broecker, W.S., and Peng, T.-H., 1989. The cause of the glacial to interglacial atmospheric $\mathrm{CO}_{2}$ change: a polar alkalinity hypothesis. Global Biogeochem. Cycles, 3:215-239.

Charles, C.D., and Fairbanks, R.G., 1992. Evidence from Southern Ocean sediments for the effect of North Atlantic deep-water flux on climate. Nature, 355:416-419.

Charles, C.D., Wright, J.D., and Fairbanks, R.G., 1993. Thermodynamic influences on the marine carbon isotope record. Paleoceanography, 8:691-697.

Curry, W.B., 1996. Late Quaternary deep circulation in the western equatorial Atlantic. In Wefer, G., Berger, W.H., Siedler, G. (Eds.), The South Atlantic: Present and Past Circulation: Berlin (Springer), 577-598.

Curry, W.B., Duplessy, J.C., Labeyrie, L.D., and Shackleton, N.J., 1988. Changes in the distribution of $\delta^{13} \mathrm{C}$ of deep water $\Sigma \mathrm{CO}_{2}$ between the last glacial and the Holocene. Paleoceanography, 3:317-341.

Curry, W.B., and Lohmann, G.P., 1990. Reconstructing past particle fluxes in the tropical Atlantic Ocean. Paleoceanography, 5:487-505.

Duplessy, J.-C., Shackleton, N.J., Fairbanks, R.G., Labeyrie, L.D., Oppo, D., and Kallel, N., 1988. Deepwater source variations during the last climatic cycle and their impact on the global deepwater circulation. Paleoceanography, 3:343-360. 
Curry, W.B., Shackleton, N.J., Richter, C., et al., 1995. Proc. ODP, Init. Repts., 154: College Station, TX (Ocean Drilling Program).

Goericke, R., and Fry, B., 1994. Variations of marine plankton $\delta^{13} \mathrm{C}$ with latitude, temperature and dissolved $\mathrm{CO}_{2}$ in the world ocean. Global Biogeochem. Cycles, 8:85-90.

Imbrie, J., Boyle, E.A., Clemens, S.C., Duffy, A., Howard, W.R., Kukla, G., Kutzbach, J., Martinson, D.G., McIntyre, A., Mix, A.C., Molfino, B., Morley, J.J., Peterson, L.C., Pisias, N.G., Prell, W.L., Raymo, M.E., Shackleton, N.J., and Toggweiler, J.R., 1992. On the structure and origin of major glaciation cycles, 1. Linear responses to Milankovitch forcing. Paleoceanography, 7:701-738.

, 1993. On the structure and origin of major glaciation cycles, 2. The 100,000-year cycle. Paleoceanography, 8:699-736.

Jansen, E., Bleil, U., Henrich, R., Kringstad, L., and Slettemark, B., 1988. Paleoenvironmental changes in the Norwegian Sea and Northeast Atlantic during the last 2.8 m.y.: Deep Sea Drilling Project/Ocean Drilling Program Sites 610, 642, 643, and 644. Paleoceanography, 3:563-581.

Kroopnick, P., 1980. The distribution of ${ }^{13} \mathrm{C}$ in the Atlantic Ocean. Earth Planet. Sci. Lett., 49:469-484.

1985. The distribution of ${ }^{13} \mathrm{C}$ of $\Sigma \mathrm{CO}_{2}$ in the world oceans. DeepSea Res. Part A, 32:57-84.

Laskar, J., 1990. The chaotic motion of the solar system: a numerical estimate of the size of the chaotic zones. Icarus, 88:266-291.

Laskar, J., Joutel, F., and Boudin, F., 1993. Orbital, precessional, and insolation quantities for the earth from $-20 \mathrm{Myr}$ to $+10 \mathrm{Myr}$. Astron. Astrophys., 270:522-533.

Lourens, L.J., Hilgen, F.J., Zachariasse, W.J., van Hoof, A.A.M., Antonarakou, A., and Vergnaud-Grazzini, C., 1996. Evaluation of the Plio-Pleistocene astronomical time scale. Paleoceanography, 11:391-413.

Mackensen, A., Hubberten, H.W., Bickert, T., Fischer, G., and Fütterer, D.K., 1993. $\delta^{13} \mathrm{C}$ in benthic foraminiferal tests of Fontbotia wuellerstorfi (SCHWAGER) relative to $\delta^{13} \mathrm{C}$ of dissolved inorganic carbon in Southern Ocean deep-water: implications for glacial ocean circulation models. Paleoceanography, 8:587-610.

Mix, A.C., and Fairbanks, N.G., 1985. North Atlantic surface-ocean control of Pleistocene deep ocean circulation. Earth Planet. Sci. Lett., 73:231243.

Mix, A.C., Pisias, N.G., Rugh, W., Wilson, J., Morey, A., and Hagelberg, T.K., 1995. Benthic foraminiferal stable isotope record from Site 849: 05 Ma. In Pisias, N.G., Mayer, L.A., Janecek, T.R., Palmer-Julson, A., and van Andel, T.H. (Eds.), Proc. ODP, Sci. Results, 138: College Station, TX (Ocean Drilling Program), 371-412.

Oppo, D.W., and Fairbanks, R.G., 1987. Variability in the deep and intermediate water circulation of the Atlantic Ocean during the past 25,000 years: Northern Hemisphere modulation of the Southern Ocean. Earth Planet. Sci. Lett., 86:1-15.
Oppo, D.W., Fairbanks, R.G., Gordon, A.L., and Shackleton, N.J., 1990. Late pleistocene Southern Ocean $\delta^{13} \mathrm{C}$ variability: North Atlantic deep water modulation of atmospheric $\mathrm{CO}_{2}$. Paleoceanography, 5:43-54.

Oppo, D.W., Raymo, M.E., Lohmann, G.P., Mix, A.C., Wright, J.D., and Prell, W.L., 1995. $\delta^{13} \mathrm{C}$ record of upper North Atlantic deep water during the past 2.6 m.y. Paleoceanography, 10:373-394.

Oppo, D.W., and Rosenthal, Y., 1994. Cd/Ca changes in a deep Cape Basin core over the past 730,000 years: response of circumpolar deepwater variability to northern hemisphere ice sheet melting? Paleoceanography, 9:661-676.

Raymo, M.E., Hodell, D., and Jansen, E., 1992. Response of deep ocean circulation to initiation of Northern Hemisphere glaciation (3-2 Ma). Paleoceanography, 7:645-672.

Raymo, M.E., Ruddiman, W.F., Shackleton, N.J., and Oppo, D.W., 1990. Evolution of Atlantic-Pacific $\delta^{13} \mathrm{C}$ gradients over the last 2.5 m.y. Earth Planet. Sci. Lett., 97:353-368.

Reid, J.L., 1989. On the total geostrophic circulation of the South Atlantic Ocean: flow patterns, tracers, and transports. Progr. Oceanogr., 23:149244.

Sarnthein, M., Winn, K., Jung, S., Duplessy, J.-C., Labeyrie, L., Erlenkeuser, H., and Ganssen, G., 1994. Changes in East Atlantic deep-water circulation over the last 30,000 years: eight-time-slice reconstructions. Paleoceanography, 9:209-267.

Shackleton, N.J., Berger, A., and Peltier, W.A., 1990. An alternative astronomical calibration of the lower Pleistocene timescale based on ODP Site 677. Trans. R. Soc. Edinburgh: Earth Sci., 81:251-261.

Shackleton, N.J., Hall, M.A., and Pate, D., 1995. Pliocene stable isotope stratigraphy of Site 846. In Pisias, N.G., Mayer, L.A., Janecek, T.R., Palmer-Julson, A., and van Andel, T.H. (Eds.), Proc. ODP, Sci. Results, 138: College Station, TX (Ocean Drilling Program), 337-355.

Tiedemann, R., 1991. Acht Millionen Jahre Klimageschichte von Nordwest Afrika und Paleaozeanographie des Angrenzenden Atlantiks: Hochaufosende Zeitreihen von ODP Sites 658-661 [Ph.D. thesis]. Geol.-Palaeont. Inst., Univ. Kiel, Ber. 46.

Tiedemann, R., Sarnthein, M., and Shackleton, N.J., 1994. Astronomic timescale for the Pliocene Atlantic $\delta^{18} \mathrm{O}$ and dust flux records of Ocean Drilling Program Site 659. Paleoceanography, 9:619-638.

Zahn, R., Winn, K., and Sarnthein, M., 1986. Benthic foraminiferal $\delta^{13} \mathrm{C}$ and accumulation rates of organic carbon: Uvigerina peregrina group and Cibicidoides wuellerstorfi. Paleoceanography, 1:27-42.

Date of initial receipt: 6 December 1995

Date of acceptance: 29 June 1996

Ms 154SR-110 
APPENDIX 1. Age models for Leg 154 Sites 925 through 929 from 0 to 2.6 Ma.

\begin{tabular}{|c|c|c|c|c|c|}
\hline $\begin{array}{l}\text { Age } \\
\text { (Ma) }\end{array}$ & $\begin{array}{l}\text { Site } 925 \\
\text { depth } \\
(\mathrm{mcd})\end{array}$ & $\begin{array}{l}\text { Site } 926 \\
\text { depth } \\
\text { (mcd) }\end{array}$ & $\begin{array}{l}\text { Site } 927 \\
\text { depth } \\
(\mathrm{mcd})\end{array}$ & $\begin{array}{l}\text { Site } 928 \\
\text { depth } \\
(\mathrm{mcd})\end{array}$ & $\begin{array}{c}\text { Site } 929 \\
\text { depth } \\
\text { (mcd) }\end{array}$ \\
\hline 0.000 & 0.00 & 0.00 & 0.00 & 0.00 & 0.00 \\
\hline 0.021 & 0.98 & 0.95 & 1.22 & 1.01 & 1.05 \\
\hline 0.043 & 1.93 & 1.95 & 2.30 & 2.05 & 2.35 \\
\hline 0.068 & 3.03 & 3.05 & 3.74 & 3.19 & 3.85 \\
\hline 0.091 & 3.63 & 3.60 & 4.49 & 3.76 & 4.55 \\
\hline 0.112 & 4.43 & 4.35 & 5.44 & 4.53 & 5.49 \\
\hline 0.138 & 5.43 & 5.35 & 6.70 & 5.68 & 6.66 \\
\hline 0.161 & 6.53 & 6.38 & 7.97 & 6.82 & 7.96 \\
\hline 0.205 & 8.15 & 8.10 & 10.20 & 8.68 & 9.78 \\
\hline 0.229 & 9.15 & 9.19 & 11.60 & 9.76 & 10.85 \\
\hline 0.252 & 9.84 & 9.88 & 12.40 & 10.43 & 11.55 \\
\hline 0.277 & 10.95 & 11.03 & 13.76 & 11.57 & 12.91 \\
\hline 0.299 & 11.85 & 11.80 & 14.75 & 12.37 & 13.77 \\
\hline 0.321 & 12.55 & 12.40 & 15.48 & 12.96 & 14.31 \\
\hline 0.344 & 13.47 & 13.20 & 16.47 & 13.77 & 15.15 \\
\hline 0.396 & 15.75 & 15.22 & 18.96 & 15.68 & 17.14 \\
\hline 0.416 & 16.75 & 16.05 & 20.12 & 16.53 & 17.98 \\
\hline 0.433 & 17.85 & 16.95 & 21.28 & 17.03 & 19.02 \\
\hline 0.473 & 19.35 & 17.85 & 22.51 & 18.68 & 19.90 \\
\hline 0.515 & 20.75 & 19.18 & 24.16 & 20.12 & 21.40 \\
\hline 0.545 & 21.86 & 20.15 & 25.51 & 21.30 & 22.82 \\
\hline 0.565 & 22.26 & 20.56 & 26.02 & 21.72 & 23.53 \\
\hline 0.588 & 22.96 & 21.22 & 26.92 & 22.46 & 24.10 \\
\hline 0.631 & 24.26 & 22.26 & 28.32 & 23.72 & 25.48 \\
\hline 0.659 & 25.26 & 23.16 & 29.77 & 24.96 & 26.66 \\
\hline 0.679 & 25.86 & 23.79 & 30.46 & 25.60 & 27.52 \\
\hline 0.701 & 26.51 & 24.35 & 31.31 & 26.21 & 28.16 \\
\hline 0.720 & 26.90 & 24.80 & 31.86 & 26.68 & 28.63 \\
\hline 0.756 & 27.68 & 25.70 & 33.06 & 27.80 & 29.58 \\
\hline 0.795 & 29.15 & 27.15 & 34.90 & 29.34 & 31.04 \\
\hline 0.832 & 30.32 & 28.40 & 36.45 & 30.55 & 32.54 \\
\hline 0.853 & 30.65 & 28.83 & 36.85 & 30.81 & 32.87 \\
\hline 0.873 & 31.30 & 29.40 & 37.54 & 31.34 & 33.42 \\
\hline 0.891 & 31.82 & 30.00 & 38.20 & 31.84 & 34.05 \\
\hline 0.923 & 32.72 & 31.15 & 39.50 & 32.84 & 35.21 \\
\hline 0.965 & 33.82 & 32.05 & 40.54 & 33.74 & 36.01 \\
\hline 0.985 & 34.52 & 32.70 & 41.30 & 34.34 & 36.71 \\
\hline 1.010 & 35.32 & 33.40 & 42.15 & 35.01 & 37.37 \\
\hline 1.059 & 36.42 & 34.53 & 43.83 & 36.16 & 38.54 \\
\hline 1.081 & 37.24 & 35.15 & 44.64 & 36.91 & 39.44 \\
\hline 1.101 & 37.70 & 35.54 & 45.15 & 37.38 & 39.86 \\
\hline 1.136 & 38.90 & 36.60 & 46.39 & 38.51 & 41.06 \\
\hline 1.175 & 39.99 & 37.55 & 47.66 & 39.72 & 42.19 \\
\hline 1.213 & 41.14 & 38.55 & 49.01 & 40.89 & 43.54 \\
\hline 1.252 & 42.18 & 39.50 & 50.26 & 41.94 & 44.60 \\
\hline 1.269 & 42.74 & 40.05 & 50.94 & 42.49 & 45.11 \\
\hline 1.298 & 43.60 & 40.90 & $52.10 / 53.60 *$ & 43.47 & 46.03 \\
\hline 1.328 & 44.78 & 41.90 & 54.59 & 44.67 & 47.13 \\
\hline 1.386 & 46.36 & 43.55 & 56.35 & 46.07 & 48.48 \\
\hline 1.419 & 47.21 & 44.50 & 57.50 & 46.88 & 49.52 \\
\hline 1.461 & 48.37 & 45.80 & 58.94 & 48.16 & 50.77 \\
\hline 1.502 & 49.22 & 46.82 & 60.04 & 49.13 & 51.87 \\
\hline 1.536 & 50.50 & 48.26 & 61.60 & 50.53 & 53.14 \\
\hline 1.555 & 50.97 & 48.80 & 62.09 & 51.01 & 53.59 \\
\hline 1.593 & 52.28 & 50.26 & 63.44 & 52.21 & 54.80 \\
\hline 1.632 & 53.33 & 51.56 & 64.49 & 53.20 & 55.80 \\
\hline 1.671 & 54.43 & 52.60 & 65.85 & 54.29 & 57.14 \\
\hline 1.706 & 55.63 & 53.80 & 67.32 & 55.60 & 58.46 \\
\hline 1.727 & 56.25 & 54.45 & 68.04 & 56.32 & 58.95 \\
\hline 1.746 & 56.78 & 54.95 & 68.76 & 56.98 & 59.58 \\
\hline 1.796 & 58.36 & 56.50 & 70.53 & 58.68 & 61.15 \\
\hline 1.820 & 59.04 & 57.21 & 71.35 & 59.26 & 61.80 \\
\hline 1.841 & 59.66 & 57.80 & 72.06 & 59.90 & 62.50 \\
\hline 1.863 & 60.22 & 58.35 & 72.93 & 60.68 & 63.10 \\
\hline 1.882 & 60.88 & 59.00 & 73.58 & 61.18 & 63.70 \\
\hline 1.913 & 61.90 & 60.00 & 74.77 & 62.32 & 64.80 \\
\hline 1.955 & 63.21 & 61.35 & 76.24 & 63.57 & 66.11 \\
\hline 1.993 & 64.27 & 62.25 & 77.43 & 64.41 & 66.92 \\
\hline 2.050 & 65.71 & 63.61 & 78.93 & 65.92 & 68.22 \\
\hline 2.084 & 66.90 & 64.70 & 80.34 & 67.08 & 69.48 \\
\hline 2.127 & 68.24 & 66.02 & 82.01 & 68.28 & 70.76 \\
\hline 2.174 & 69.54 & 67.16 & 83.53 & 69.63 & 72.15 \\
\hline 2.199 & 70.94 & 68.45 & 85.28 & 71.04 & 73.17 \\
\hline 2.219 & 71.63 & 69.10 & 86.14 & 71.73 & 73.92 \\
\hline 2.242 & 72.47 & 69.95 & 87.16 & 72.63 & 74.61 \\
\hline 2.289 & 73.98 & 71.45 & 88.97 & 74.23 & 76.02 \\
\hline 2.314 & 74.84 & 72.38 & 90.05 & 75.18 & 76.92 \\
\hline 2.334 & 75.32 & 72.78 & 90.59 & 75.84 & 77.48 \\
\hline 2.341 & & & $90.78 * *$ & & \\
\hline 2.358 & & & $90.79 * *$ & & \\
\hline 2.373 & 76.34 & 73.75 & 91.28 & 76.82 & 78.43 \\
\hline 2.409 & 77.36 & 74.83 & 92.58 & 77.82 & 79.61 \\
\hline 2.446 & 78.29 & 75.83 & 93.58 & 78.86 & 80.31 \\
\hline 2.486 & 79.89 & 77.37 & 95.47 & 80.57 & 81.91 \\
\hline 2.531 & 81.18 & 78.69 & 96.89 & 82.12 & 83.54 \\
\hline 2.601 & 83.49 & 81.33 & 99.40 & 84.51 & 85.71 \\
\hline
\end{tabular}

APPENDIX 2. Revised age model for DSDP Site 607 used in this study.

\begin{tabular}{rccccc}
\hline $\begin{array}{r}\text { Depth } \\
\text { (mcd) }\end{array}$ & $\begin{array}{c}\text { Age } \\
\text { (Ma) }\end{array}$ & $\begin{array}{l}\text { Depth } \\
\text { (mcd) }\end{array}$ & $\begin{array}{l}\text { Age } \\
\text { (Ma) }\end{array}$ & $\begin{array}{r}\text { Depth } \\
\text { (mcd) }\end{array}$ & $\begin{array}{c}\text { Age } \\
\text { (Ma) }\end{array}$ \\
\hline 9.32 & 0.245 & 48.87 & 1.195 & 86.6 & 2.075 \\
14.03 & 0.345 & 52.54 & 1.288 & 90.63 & 2.162 \\
17.78 & 0.422 & 54.65 & 1.332 & 94.45 & 2.245 \\
20.72 & 0.535 & 57.66 & 1.416 & 99.85 & 2.364 \\
24.88 & 0.628 & 59.36 & 1.458 & 103.79 & 2.443 \\
29.23 & 0.719 & 62.7 & 1.542 & 107.69 & 2.519 \\
32.32 & 0.794 & 64.6 & 1.574 & 111.29 & 2.606 \\
34.87 & 0.874 & 68.03 & 1.652 & 114.78 & 2.700 \\
36.97 & 0.916 & 72.31 & 1.749 & 119.58 & 2.817 \\
38.83 & 0.963 & 74.21 & 1.795 & 121.99 & 2.920 \\
42.42 & 1.038 & 79.47 & 1.916 & & \\
46.02 & 1.128 & 83.06 & 1.993 & & \\
\hline
\end{tabular}

Note: $*=$ superfluous cycle in Site $927, * *=$ missing cycle in Site 927. 